\title{
Anti-RNA Polymerase III Antibodies in Systemic Sclerosis
}

\author{
Andrew Kelly', Chris T. Derk ${ }^{2}$ \\ ${ }^{1}$ Department of Medicine, Pennsylvania Hospital, Philadelphia, PA, USA \\ ${ }^{2}$ Division of Rheumatology, University of Pennsylvania, Philadelphia, PA, USA \\ Email: ${ }^{*}$ Chris.Derk@uphs.upenn.edu
}

Received 8 July 2015; accepted 16 August 2015; published 19 August 2015

Copyright (C) 2015 by authors and Scientific Research Publishing Inc.

This work is licensed under the Creative Commons Attribution International License (CC BY). http://creativecommons.org/licenses/by/4.0/

(c) (i) Open Access

\begin{abstract}
Anti-RNA Polymerase III has been recognized as an important autoantibody in Systemic Sclerosis and it is now included in the 2013 ACR/EULAR classification criteria for Systemic Sclerosis. With this manuscript we attempt to review the current data on anti-RNA polymerase II as it relates to Systemic Sclerosis.
\end{abstract}

Keywords

Autoantibodies, Systemic Sclerosis, Scleroderma, Anti-RNA Polymerase III, Cancer

\section{Introduction}

Systemic Sclerosis (SSc) is an autoimmune connective tissue disorder characterized by tissue fibrosis, vascular dysfunction, both structural and functional, early cellular infiltration of affected tissues, with local cytokine and growth factor upregulation as well as B-cell abnormalities resulting in the production of autoantibodies. It affects multiple organ systems, has a peak incidence between 20 - 50 years of age, and it can be chronic and progressive in naturewith female predominance [1] [2]. SSc is subdivided based on skin involvementinto limited cutaneous Systemic Sclerosis (lcSSc) which involves the skin distal to the knees and elbows, and diffuse cutaneous Systemic Sclerosis (dcSSc) which involves the skin proximal to the knees and the elbows. Less common forms of SSc are sclerosis sine scleroderma, overlap syndromes, and undifferentiated scleroderma. Raynaud's phenomenon, skin tightness/thickening, myalgias, arthralgias, digital ulcers, pulmonary arterial hypertension (PAH), gastrointestinal symptoms, and renal impairment are some of the disease manifestations of SSc. The etiology of the disease is unknown but believed to be a combination of genetic and environmental factors [3] [4].

SSc is associated with various autoantibodies including anti-centromere antibodies (sensitivity 33\%, specific-

Corresponding author. 
ity 99.9\%) and anti-topoisomerase-I antibody (sensitivity 20.2\%, specificity 100\%) that are used to predict disease type. The former is associated with lcSSc and the latter with dcSSc, and they are generally mutually exclusive [5]. Thus, these antibodies assist the clinician to identify patients at risk for certain organ system involvement, which may benefit from closer monitoring. Other autoantibodies previously established are also associated with certain manifestations of SSc, such as anti-U3-RNP with increased risk of PAH and skeletal muscle involvement [6], and anti-PM-Scl antibodies are associated with myositis [7], while high titers of rheumatoid factor, antibodies to citrullinated peptides (anti-CCP), anti-U1-RNP antibodies, anti-double stranded DNA, and anti-Smith are uncommon in patients with SSc and suggest overlap syndromes [8].

Another antibody, anti-RNA-polymerase III (anti-RNAP III) is now included in the most recent American College of Rheumatology (ACR)/EULAR classification criteria for SSc and it is used to predict disease severity [9]. The prevalence of anti-RNAP III among SSc patients has been estimated from $4 \%-22 \%$ worldwide with geoethnic variation. Higher frequency is seen in USA (8.3\%), England (11.7\%), Sweden (22\%) and lower frequency is noted in Japan (5\%) and France (4\%) [10]. More recently, a study in Belgium further supports prior results and notes 7\% prevalence of anti-RNAP III ab [11]. Similar to other autoantibodies in SSc, anti-RNAP III has a lower sensitivity, but is highly specific for SSc (sensitivity: 10\% - 20\%, specificity: 98.8\%) [12]. Moreover, it is highly associated with dcSSc, associated with scleroderma renal crisis, and skin changes. More recently, anti-RNAP III has been associated with malignancy in patients with SSc. Moinzadeh et al. examines a cohort of SSc (>2000 patients with SSc) and find significantly increased frequency of cancers among patients with antiRNAP III compared to ACA and anti-Scl-70 abs. Finally, a temporal association is suggested between onset of SSc and breast cancer. That is, among patients diagnosed with cancer within the first 36 months of SSc onset, a large number of them have anti-RNP (55.3\%) compared to ACA (23.5\%) and anti-Scl-70 (13.6\%) [13]. This will be further elaborated below. This review seeks to examine past and current literature on the anti-RNAP III antibody, its association with SSc, and potential future applications of the biomarker.

\section{Discovery and Methodology of Testing}

Antibodies to RNA Pol III were first described by Okano et al. by immunoprecipitation in a 1992 abstract [14]. However, before their more definitive paper came out, Kuwana et al. described autoantibodies from all three RNA polymerases as biomarkers for SSc [15]. Okano et al. took 252 serum samples of patients with SSc of these 161 samples precipitated specific antibodies previously described in SSc. However, the remaining sera from 91 patients produced nuclear, or nucleolar staining, or both towards a unidentified antigen. Of the 91 samples, 57 precipitated proteins that could represent RNA Pol I, II, or III. These were brokendown into 3 groups based upon protein precipitation pattern using previously identified molecular weights and structures of RNA polymerases. Group 1 exhibited proteins similar to all RNA Pol I, II, and III $(n=13)$. While group 2 was likely RNA Pol I, and II $(n=27)$, and group 3 was suspected to be RNA Pol III $(n=17)$. To confirm the hypothesis, immunoblotting studies were performed on the sera directed against anti-RNA Pol III. Afterward, immunodepletion studies were conducted on the 3 groups of sera for confirmation. Finally, immunofluoresnce studies were performed on all 57 sera. Characteristic nucleolar and nuclear RNA Pol I staining was observed in 17 patients (7 from group 1, 10 from group 2, and none from group 3). The remaining 40 sera showed only nuclear speckled staining. RNA Pol I is known to be located in nucleoli, while RNA Pol II and III are found in the nuclei. Finally, Okano et al. tested for the presence of anti-RNA Pol III ab in patients with SSc with other autoantibodies. None of these patients were found to have anti-RNA Pol III ab in addition to another autoantibody. Further analysis revealed that of the SSc patients who were positive for Anti-RNAP III ab 45\% had dcSSc (compared to 7\% with lcSSc). Finally, these patients also had significant skin thickness and were more likely to have scleroderma renal crisis [16].

Due to the time consuming and complicated nature of immunopreciptation assays and the inconsistency of indirect immunofluorescent (IIF) staining, it was difficult to employ the use of anti-RNA Pol III antibody detection in routine clinical practice. To demonstrate the difficulty with IIF, Yamasaki et al. tested three methods of RNAP III detection using 18 samples of Anti RNAP I/III samples: 1) sera were tested using immunofluorescent antinuclear antibodies on HEp-2 cell slides; 2) by anti-RNAP III ELISA; and 3) by IP assay using 35S-labeled K562 cell extract. Nucleolar staining of anti-RNAP antibody IP-positive sera was confirmed by double staining with antifibrillarin monoclonal antibodies. It was noted that anti-RNAP I almost always coexists with antiRNAP III ab, and are often accompanied by anti-RNAP II [17]. Anti-RNAP I ab are believed to localize to nuc- 
leoli. If this were the case, then IIF could be used as a screening test prior to anti-RNAP III ELISA. All 18 samples showed nuclear speckled/homogeneous staining, but nucleolar staining was clearly present only $42 \%$ of the time, while $26 \%$ was not obviously present, and $32 \%$ of the time it was unrecognizable, making the majority of nucleolar staining samples unclear to unrecognizable. Thus, detection using enzyme-linked immunosorbent assay (ELISA) was developed [18]. However, before an ELISA could be developed an RNA Pol III epitope needed to be identified.

\section{Anti-RNA Pol III Epitope}

Kuwana et al. identified an RNA Pol III immunodominant epitope and developed an ELISA in 2002. RNA Pol I and III are multiprotein complexes consisting of $>12$ subunits, thus the development of a subunit-specific assay required recognition of the antigenic subunit recognized by anti-RNAP I/III positive sera. Prior investigation revealed RNAP III-specific 62-kd and 155-kd subunits are recognized by nearly all SSc sera containing anti-RNAP I/III abs, which corresponded to RNAP III subunits RPC62 and RPC155 [19]-[21]. cDNA which encodes the nucleotide sequences for the complete open-reading frames were then identified [20] [22]. Afterward, Kuwana et al. then further examined the epitopes using a series of recombinant fragments expressed in Escherichia coli. These recombinant fragments were used to express the major epitope as antigen, which led to the development of an ELISA for detection of anti-RNAP I/III antibodies.

\section{Pathogenesi}

To date, the mechanism in which anti-RNA Pol III antibodies cause disease remains unclear. Based on the epitope described above, the subunits are highly conserved throughout multiple organisms (yeast, bacteria, mammalian cells), and it has been suggested that molecular mimicry may lead to the production of antibodies against RNA Pol III [21].

\section{RNA Pol III Ab Associations}

\subsection{Malignancy}

Cancer has been associated with SSc ranging from 3.6\% - 10.7\% in patients with SSc and 75\% compared to the general population [23] [24]. Malignancy has been noted more frequently with dcSSc compared to lcSSc [13]. Prior studies have not found significant relationship between ACA and anti-Scl-70 antibodies in patients with SSc and malignancy. However, more recent investigation has noted association with SSc patients with RNA Pol III ab and malignancy [25] [26]. Wooten in a 2008 review article describes lung cancer as the major malignancy, followed by breast cancer, and then gastrointestinal cancers (esophageal (6.2\%) being most common), urogenital, lymphomas and other hematologic cancers [24]. More recently, Bonifaze et al. further confirmed SSc and cancer risk [23] again noting the strong association with lung cancer, but did not show an association with breast cancer. Most recently, Moinzadeh et al. conducted the largest population study to date on SSc and cancer ( $n$-2177 with SSc, $n$-154 pts with SSc and cancer) and found increased frequency of breast cancer (42.2\%) then lung cancer (10.4\%), and hematological cancers (12.3\%) and GI or gynecological (11\%). The cohort was 85\% female and $63 \%$ had lcSSc. Abs to ACAs, anti-Scl-70 and Anti RNP ab were measured and found to contain $26 \%, 18.2 \%$, and $26.6 \%$ respectively. They noted a statistically significant higher frequency of malignancy in patients with anti-RNP abs than those without cancers ( $26.6 \%$ vs. $12.2 \%$ respectively P $<0.001$ ), while no statistically significant differences were noted in ACA and anti-Scl-70 abs.

\subsection{Temporal Relationship}

Investigation into the timing of malignancy diagnosis with respect to SSc diagnosis has yielded some associations of interest. Pulmonary cancer has been associated with long standing SSc $>5$ years from dx of SSc and closely associated with pulmonary fibrosis, while breast cancer appears to have a closer temporal relationship between onset of SSc and cancer [23] [27]. Launay et al. reported a less than 12 month duration between onset of breast cancer and diagnosis of systemic sclerosis [28]. Scope noted $75 \%$ of reported breast cancer cases and SSc were diagnosed within 3 years of each other [29]. Moinzadeh et al. noted a statistically significant number of patients with SSc and anti-RNP III abs were diagnosed with cancer (again breast cancer most common at 
$46 \%$ ) within the first 3 years, and had nearly $6 x$ higher odds of developing cancer in the first 3 years compared to patients without anti-RNAP abs. They found no significant cancer development with patients from $36-120$ mo after SSc onset. This temporal relationship between SSc and malignancy suggests the possibility of SSc representing a paraneoplastic syndrome in which the immune system is responding to malignancy. There has been implication of abnormal RNAP activity in cancer cells from breast and lung carcinomas as well as fibroblasts transformed by polyomavirus. Thus, it has been suggested that repression of tumor suppressor genes p53 and retinoblastoma and/or activation of oncogene product c-Myc may lead to enhanced RNAP activity. Although, no biologic basis for an association between specific autoantibody subtypes against nucleolar RNA associated proteins and malignancy has been established to date. However, the presence of anti-RNAP ab may initiate an anti-tumor immune response, which in the appropriate setting may cross-react against specific host tissue resulting in damage [30]-[34].

\section{Conclusion}

Anti-RNAP III antibody is highly specific but not sensitive for SSc. It is associated with dcSSc and often seen with skin thickening and renal crisis. Assays for detection of the antibody have improved from immunoprecipitation, to discovering the inability to use IIF, to now commercially available ELISA. There appears to be an association with SSc and malignancy and some evidence implicating that anti-RNAP III is elevated in these patients. Anti-RNAP III is, to date, the only antibody in SSc to show a significant relationship to malignancy and temporal relationship with breast cancer. However, there is conflicting data on whether breast cancer is associated with SSc. More investigation into the biologic underpinnings between anti-RNAP III and malignancy should be explored. Individuals with SSc who have anti-RNAP III ab and are at high risk for malignancy, may warrant appropriate screening.

\section{References}

[1] Mayes, M.D., Lacey Jr., J.V., Beebe-Dimmer, J., Gillespie, B.W., Cooper, B., Laing, T.J. and Schottenfeld, D. (2003) Prevalence, Incidence, Survival, and Disease Characteristics of Systemic Sclerosis in a Large Us Population. Arthritis \& Rheumatism, 48, 2246-2255. http://dx.doi.org/10.1002/art.11073

[2] Nihtyanova, S.I., Parker, J.C., Black, C.M., Bunn, C.C. and Denton, C.P. (2009) A Longitudinal Study of Anti-RNA Polymerase III Antibody Levels in Systemic Sclerosis. Rheumatology, 48, 1218-1221.

[3] Arnett, F.C., Cho, M., Chatterjee, S., Aguilar, M.B., Reveille, J.D. and Mayes, M.D. (2001) Familial Occurrence Frequencies and Relative Risks for Systemic Clerosis (Scleroderma) in Three United States Cohorts. Arthritis \& Rheumatism, 44, 1359-1362. http://dx.doi.org/10.1002/1529-0131(200106)44:6<1359::AID-ART228>3.0.CO;2-S

[4] Garabrant, D.H., Lacey Jr., J.V., Laing, T.J., Gillespie, B.W., Mayes, M.D., Cooper, B.C. and Schottenfeld, D. (2003) Scleroderma and Solvent Exposure among Women. American Journal of Epidemiology, 157, 493-500. http://dx.doi.org/10.1093/aje/kwf223

[5] Reveille, J.D. and Solomon, D.H. (2003) American College of Rheumatology Ad-Hoc Committee of Immunologic Testing Guidelines. Evidence-Based Guidelines for the Use of Immunologic Tests: Anticentromere, Scl-70, and Nucleolar Antibodies. Arthritis \& Rheumatism, 49, 399-412. http://dx.doi.org/10.1002/art.11113

[6] Aggarwal, R., Lucas, M., Fertig, N., Oddis, C.V. and Medsger Jr., T.A. (2009) Anti-U3 RNP Autoantibodies in Systemic Sclerosis. Arthritis \& Rheumatism, 60, 1112-1118. http://dx.doi.org/10.1002/art.24409

[7] Oddis, C.V., Okano, Y., Rudert, W.A., Trucco, M., Duquesnoy, R.J. and Medsger Jr., T.A. (1992) Serum Autoantibody to the Nucleolar Antigen PM-Scl. Clinical and Immunogenetic Associations. Arthritis \& Rheumatism, 35, 12111217. http://dx.doi.org/10.1002/art.1780351014

[8] Pakozdi, A., Nihtyanova, S., Moinzadeh, P., Ong, V.H., Black, C.M. and Denton, C.P. (2011) Clinical and Serological Hallmarks of Systemic Sclerosis Overlap Syndromes. Journal of Rheumatology, 38, 2406-2409. http://dx.doi.org/10.3899/jrheum.101248

[9] van den Hoogen, F., Khanna, D., Fransen, J., Johnson, S.R., Baron, M., et al. (2013) Classification Criteria for Systemic Sclerosis: An American Collge of Rheumatology/European League against Rheumatism Collaborative Initiative. Arthritis \& Rheumatism, 65, 2737-2747. http://dx.doi.org/10.1002/art.38098

[10] Koenig, M., Dieudé, M. and Senécal, J.L. (2008) Predictive Value of Antinuclear Autoantibodies: The Lessons of the Systemics Clerosis Autoantibodies. Autoimmunity Reviews, 7, 588-593.

[11] Maes, L., Blockmans, D., Verschueren, P., Westhovens, R., De Beéck, K.O., Vermeersch, P., Van den Bergh, K., Bur- 
lingame, R.W., Mahler, M. and Bossuyt, X. (2010) Anti-PM/Scl-100 and Anti-RNA-Polymerase III Antibodies in Scleroderma. Clinica Chimica Acta, 411, 965-971. http://dx.doi.org/10.1016/j.cca.2010.03.018

[12] Satoh, T., Ishikawa, O., Ihn, H., Endo, H., Kawaguchi, Y., Sasaki, T., Goto, D., Takahashi, K., Takahashi, H., Misaki, Y., Mimori, T., Muro, Y., Yazawa, N., Sato, S., Takehara, K. and Kuwana, M. (2009) Clinical Usefulness of AntiRNA Polymerase III Antibody Measurement by Enzyme-Linked Immunosorbent Assay. Rheumatology, 48, 1570-1574. http://dx.doi.org/10.1093/rheumatology/kep290

[13] Moinzadeh, P., Fonseca, C., Hellmich, M., Shah, A.A., Chighizola, C., Denton, C.P. and Ong, V.H. (2014) Association of Anti-RNA Polymerase III Autoantibodies and Cancer in Scleroderma. Arthritis Research \& Therapy, 16, R53.

[14] Okano, Y., Steen, V.D. and Medsger Jr., T.A. (1992) Serum Autoantibodies Reactive with RNA Polymerase III (RP3), A Major Autoantigen in Systemic Sclerosis with Diffuse Cutaneous Involvement. Arthritis \& Rheumatism, 35, S3.

[15] Kuwana, M., Kaburaki, J., Mimori, T., Tojo, T. and Homma, M. (1993) Autoantibody Reactive with Three Classes of RNA Polymerases in Sera from Patients with Systemic Sclerosis. Journal of Clinical Investigation, 91, 1399-1404. http://dx.doi.org/10.1172/JCI116343

[16] Okano, Y., Steen, V.D. and Medsger Jr., T.A. (1993) Autoantibody Reactive with RNA Polymerase III in Systemic Sclerosis. Annals of Internal Medicine, 119, 1005-1013. http://dx.doi.org/10.7326/0003-4819-119-10-199311150-00007

[17] Hirakata, M., Okano, Y., Pati, U., Suwa, A., Medsger Jr., T.A., Hardin, J.A. and Craft, J. (1993) Identification of Autoantibodies to RNA Polymerase II. Occurrence in Systemic Sclerosis and Association with Autoantibodies to RNA Polymerases I and III. Journal of Clinical Investigation, 91, 2665-2672. http://dx.doi.org/10.1172/JCI116505

[18] Yamasaki, Y., Honkanen-Scott, M., Hernandez, L., Ikeda, K., Barker, T., Bubb, M.R., Narain, S., Richards, H.B., Chan, E.K., Reeves, W.H. and Satoh, M. (2006) Nucleolar Staining Cannot Be Used as a Screening Test for the Scleroderma Marker Anti-RNA Polymerase I/III Antibodies. Arthritis \& Rheumatism, 54, 3051-3056. http://dx.doi.org/10.1002/art.22043

[19] Kuwana, M., Okano, Y., Kaburaki, J., Medsger Jr., T.A. and Wright, T.M. (1999) Autoantibodies to RNA Polymerases Recognize Multiple Subunits and Demonstrate Cross-Reactivity with RNA Polymerase Complexes. Arthritis \& Rheumatism, 42, 275-284. http://dx.doi.org/10.1002/1529-0131(199902)42:2<275::AID-ANR9>3.0.CO;2-P

[20] Wang, Z. and Roeder, R.G. (1997) Three Human RNA Polymerase III-Specific Subunits from a Subcomplex with a Selective Function in Specific Transcription Initiation. Genes \& Development, 11, 1315-1326. http://dx.doi.org/10.1101/gad.11.10.1315

[21] Kuwana, M., Kimura, K. and Kawakami, Y. (2002) Identification of an Immunodominant Epitope on RNA Polymerase III Recognized by Systemic Sclerosis Sera: Application to Enzyme-Linked Immunosorbent Assay. Arthritis \& Rheumatism, 46, 2742-2747. http://dx.doi.org/10.1002/art.10521

[22] Sepehri, S. and Hernandez, N. (1997) The Largest Subunit of Human RNA Polymerase III Is Closely Related to the Largest Subunit of Yeast and Trypanosome RNA Polymerase III. Genome Research, 7, 1006-1019.

[23] Bonifazi, M., Tramacere, I., Pomponio, G., Gabrielli, B., Avvedimento, E.V., La Vecchia, C., Negri, E. and Gabrielli, A. (2013) Systemic Sclerosis (Scleroderma) and Cancer Risk: Systematic Review and Meta-Analysis of Observational Studies. Rheumatology, 52, 143-154. http://dx.doi.org/10.1093/rheumatology/kes303

[24] Wooten, M. (2008) Systemic Sclerosis and Malignancy: A Review of the Literature. Southern Medical Journal, 101, 59-62. http://dx.doi.org/10.1097/SMJ.0b013e31815838ce

[25] Airò, P., Ceribelli, A., Cavazzana, I., Taraborelli, M., Zingarelli, S. and Franceschini, F. (2011) Malignancies in Italian Patients with Systemic Sclerosis Positive for Anti-RNA Polymerase III Antibodies. The Journal of Rheumatology, 38, 1329-1334. http://dx.doi.org/10.3899/jrheum.101144

[26] Shah, A.A., Rosen, A., Hummers, L., Wigley, F. and Casciola-Rosen, L. (2010) Close Temporal Relationship between Onset of Cancer and Scleroderma in Patients with RNA Polymerase I/III Antibodies. Arthritis \& Rheumatism, 62, 2787-2795. http://dx.doi.org/10.1002/art.27549

[27] Yang, Y., Fujita, J., Tokuda, M., Bandoh, S. and Ishida, T. (2001) Lung Cancer Associated with Several Connective Tissue Diseases: With a Review of Literature. Rheumatology International, 21, 106-111. http://dx.doi.org/10.1007/s00296-001-0141-3

[28] Launay, D., Le Berre, R., Hatron, P.Y., Peyrat, J.-P., Hachulla, E., Devulder, B., et al. (2004) Association between Systemic Sclerosis and Breast Cancer: Eight New Cases and Review of the Literature. Clinical Rheumatology, 23, 516522. http://dx.doi.org/10.1007/s10067-004-0940-5

[29] Scope, A., Sadetzki, S., Sidi, Y., Barzilai, A., Trau, H., Kaufman, B., Catane, R. and Ehrenfeld, M. (2006) Breast Cancer and Scleroderma. SKINmed: Dermatology for the Clinician, 5, 18-24. http://dx.doi.org/10.1111/j.1540-9740.2006.04448.x

[30] Chen, W., Böcker, W., Brosius, J. and Tiedge, H. (1997) Expression of Neural BC200 RNA in Human Tumours. The 
Journal of Pathology, 183, 345-351.

http://dx.doi.org/10.1002/(SICI)1096-9896(199711)183:3<345::AID-PATH930>3.0.CO;2-8

[31] Felton-Edkins, Z.A. and White, R.J. (2002) Multiple Mechanisms Contribute to the Activation of RNA Polymerase III Transcription in Cells Transformed by Papovaviruses. The Journal of Biological Chemistry, 277, 48182-48191. http://dx.doi.org/10.1074/jbc.M201333200

[32] Larminie, C.G., Sutcliffe, J.E., Tosh, K., Winter, A.G., Felton-Edkins, Z.A. and White, R.J. (1999) Activation of RNA Polymerase III Transcription in Cells Transformed by Simian Virus 40. Molecular and Cellular Biology, 19, 49274934.

[33] White, R.J. (2005) RNA Polymerases I and III, Growth Control and Cancer. Nature Reviews Molecular Cell Biology, 6, 69-78. http://dx.doi.org/10.1038/nrm1551

[34] Kenneth, N.S., Ramsbottom, B.A., Gomez-Roman, N., Marshall, L., Cole, P.A. and White, R.J. (2007) TRRAP and GCN5 Are Used by c-Myc to Activate RNA Polymerase III Transcription. Proceedings of the National Academy of Sciences of the United States of America, 104, 14917-14922. http://dx.doi.org/10.1073/pnas.0702909104 